Article

\title{
A Comparative Study of Microcystin-LR Degradation by UV-A, Solar and Visible Light Irradiation Using Bare and C/N/S-Modified Titania
}

\author{
Tamer M. Khedr ${ }^{1,2,3, *}$, Said M. El-Sheikh ${ }^{1}\left({ }^{1}\right.$, Hany M. Abdeldayem ${ }^{4} \oplus$, Adel A. Ismail ${ }^{1}$, \\ Ewa Kowalska ${ }^{3}$ (i) and Detlef W. Bahnemann ${ }^{2,5}$ (i) \\ 1 Nanomaterials and Nanotechnology Department, Central Metallurgical Research and Development \\ Institute (CMRDI) P.O. Box: 87 Helwan, Cairo 11421, Egypt; selsheikh2001@gmail.com (S.M.E.-S.); \\ adelali141@yahoo.com (A.A.I.) \\ 2 Institute of Technical Chemistry, Photocatalysis and Nanotechnology Research Unit, Leibniz Universität \\ Hannover, Callinstr. 3, D-30167 Hannover, Germany; bahnemann@iftc.uni-hannover.de \\ 3 Institute for Catalysis, Hokkaido University, N21, W10, Sapporo 001-0021, Japan; \\ kowalska@cat.hokudai.ac.jp \\ 4 Chemistry Department, Faculty of Science, Ain Shams University, 11566 Abassia, Cairo, Egypt; \\ monamohus@yahoo.com \\ 5 Laboratory Photoactive Nanocomposite Materials (Director), Saint-Petersburg State University, \\ Ulyanovskaya str. 1, Peterhof, 198504 Saint-Petersburg, Russia \\ * Correspondence: khedr.t@cat.hokudai.ac.jp or ortamerkhedr56@gmail.com; Tel.: +81-11-706-9130
}

Received: 19 September 2019; Accepted: 20 October 2019; Published: 23 October 2019

\begin{abstract}
In an endeavor to tackle environmental problems, the photodegradation of microcystin-LR (MC-LR), one of the most common and toxic cyanotoxins, produced by the cyanobacteria blooms, was examined using nanostructured $\mathrm{TiO}_{2}$ photocatalysts (anatase, brookite, anatase-brookite, and C/N/S co-modified anatase-brookite) under UV-A, solar and visible light irradiation. The tailoring of $\mathrm{TiO}_{2}$ properties to hinder the electron-hole recombination and improve MC-LR adsorption on $\mathrm{TiO}_{2}$ surface was achieved by altering the preparation $\mathrm{pH}$ value. The highest photocatalytic efficiency was $97 \%$ and $99 \%$ with degradation rate of $0.002 \mathrm{mmol} \mathrm{L}^{-1} \mathrm{~min}^{-1}$ and $0.0007 \mathrm{mmol} \mathrm{L}^{-1} \mathrm{~min}^{-1}$ under UV and solar irradiation, respectively, using a bare $\mathrm{TiO}_{2}$ photocatalyst prepared at $\mathrm{pH} 10$ with anatase to brookite ratio of ca. 1:2.5. However, the bare $\mathrm{TiO}_{2}$ samples were hardly active under visible light irradiation $(<25 \%)$ due to a large band gap. Upon UV, solar and vis irradiation, the complete MC-LR degradation $(100 \%)$ was obtained in the presence of $\mathrm{C} / \mathrm{N} / \mathrm{S}$ co-modified $\mathrm{TiO}_{2}$ with a degradation rate constant of $0.26 \mathrm{~min}^{-1}, 0.11 \mathrm{~min}^{-1}$ and $0.04 \mathrm{~min}^{-1}$, respectively. It was proposed that the remarkable activity of co-modified $\mathrm{TiO}_{2}$ might originate from its mixed-phase composition, mesoporous structure, and non-metal co-modification.
\end{abstract}

Keywords: anatase/brookite; non-metal co-modification; emerging pollutants; cyanotoxins; microcystin-LR; photodecomposition

\section{Introduction}

Cyanobacteria (blue-green algae) are naturally present in aquatic environments. The increase in nutrient concentration, global water temperature, and sunlight intensity results in cyanobacterial blooms, named harmful algal blooms (HABs) [1]. It should be pointed that, besides a decrease in ecosystem stability, HABs might also cause a production of highly active toxic compounds, known as cyanotoxins, during cell lysis, which is of special concern for drinking water sources [1-3]. Moreover, the presence of cyanotoxins can increase the chemical oxygen demand, microbial growth, and disinfection 
in the water distribution systems [3]. The intoxication resulting from cyanotoxins, present in drinking water, has been reported worldwide [3,4]. Cyanotoxins represent a significant threat to all living organisms on the earth since they can poison and even kill animals and humans. Additionally, they can also accumulate in various animals, such as fish and shellfish, and thus cause toxemia, such as shellfish poisoning [5]. Furthermore, an oxidative stress to plants by cyanotoxin results in tissue necrosis, influencing a proper plant growth [6]. For example, in 1996 in Brazil, 76 humans suffering from dialysis failure died because of the exposure to the high doses of cyanotoxins through polluted intravenous fluids [5,7]. In China, cyanotoxins were suspected of liver cancer resulting from drinking of polluted water [7-9]. Moreover, it was proposed that cyanotoxins-polluted water led to the development of colorectal cancer $[7,10]$. Cyanotoxins are classified into hepatotoxins (microcystins, nodularin), neurotoxins (anatoxins, saxitoxins, $\beta$-methylamino- L-alanine), dermatotoxins (lipopolysaccharide, lyngbyatoxins, aplysiatoxin) and cytotoxins (cylindrospermopsin) [4,7]. Microcystins (MCs), strong hepatotoxin, are considered the most widespread cyanotoxin in different environments [11,12]. So far, more than 100 variants of MCs have been identified in the environment [3]. Among them, microcystin-leucine arginine (MC-LR) is the most common and toxic [1-12]. MC-LR causes an inhibition of protein phosphatase type 1 and PP2 A, resulting in neoplasm [3]. The provisional guideline value for MCLR in drinking water should be lower than $1.0 \mu \mathrm{g} \mathrm{L}^{-1}$, as proposed by the World Health Organization (WHO) [13]. However, traditional water treatment processes are not sufficient for MC-LR removal $[1,3,13,14]$. Recently, the nanostructures photocatalysts have been considered as promising materials for environmental purification [15-25]. Among photocatalysts, nanostructure $\mathrm{TiO}_{2}$ has been considered as one of the best photocatalysts (considering efficiency and cost) for environmental remediation, especially cyanotoxins decomposition [1,26-32]. For example, Robertson et al. reported the photodegradation of MC-LR in aqueous solution (initial conditions: concentration of 50-200 $\left.\mu \mathrm{m}, \mathrm{pH} 4,33^{\circ} \mathrm{C}\right)$ in the presence of $\mathrm{TiO}_{2}\left(10 \mathrm{~g} \mathrm{~L}^{-1}\right)$ during $40 \mathrm{~min}$ illumination using xenon UV lamp (280 W UVASpot 400 Lamp, Uvalight Technology Ltd., Aberdeen, UK, spectral output: $330-450 \mathrm{~nm}$ ), and they found that the initial rate of photodegradation increased with an increase of MC-LR concentration and reached $14.60 \mu \mathrm{m} \mathrm{min}^{-1}$ for $200 \mu \mathrm{m}$ concentration [26]. Chen et al. examined the degradation of cylindrospermopsin $(\mathrm{CYN})$ by $\mathrm{TiO}_{2} / \mathrm{UV}$ photolysis [33]. They conducted the control experiments to investigate the role of direct photolysis, dark adsorption, photocatalytic oxidation, and oxygen in the degradation process. The influences of light intensity, $\mathrm{TiO}_{2}$ concentration, $\mathrm{pH}$ value, and initial concentration of CYN were studied. It was found that CYN was completely oxidized in the presence of $\mathrm{TiO}_{2}, \mathrm{O}_{2}$, and $\mathrm{UV}$ irradiation within $10 \mathrm{~min}$. The pseudo-first-order rate constants (k) increased with an increase of light intensity and $\mathrm{TiO}_{2}$ doses, and decreased with increasing initial concentration and $\mathrm{pH}$ values. Despite high activity against various pollutants, $\mathrm{TiO}_{2}$ has two main limitations: (i) electron-hole recombination, and (ii) inactivity under vis irradiation due to large band gap (e.g., ca. $3.2 \mathrm{eV}$ for anatase) $[1,12,14,28,31,34-36]$. One of the methods for UV-activity enhancement is to form mixed-phase $\mathrm{TiO}_{2}$ (anatase/rutile, anatase/brookite, and anatase/brookite/rutile), which might facilitate the charge transfer process (from one phase to another), thereby overcoming the recombination [37-40]. In our previous works, anatase/brookite mixed-phase $\mathrm{TiO}_{2}$ photocatalysts were synthesized and their superior activity was found in comparison to single phase (anatase and brookite) titania samples $[31,39,40]$. For example, anatase, brookite, and anatase/brookite mixed-phase $\mathrm{TiO}_{2}$ were prepared via a hydrothermal method, and used for photodegradation of cyanotoxin (cylindrospermopsin) under UV-Vis light irradiation. It was found that mixed-phase $\mathrm{TiO}_{2}$ exhibits $\sim 2-4$ times higher photoactivity than single-phase $\mathrm{TiO}_{2}$ [31]. On the other hand, non-metal modification allows for obtaining novel photocatalysts active also under visible light irradiation [1,3,14,28,33-50]. Triantis et al. investigated the photodegradation of MC-LR using $\mathrm{N}$-modified $\mathrm{TiO}_{2}$, and non-modified $\mathrm{TiO}_{2}$ (commercial Degussa P25, and reference $\mathrm{TiO}_{2}$ ) photocatalysts under UV-A, solar and visible light [28]. They found that all $\mathrm{TiO}_{2}$ photocatalysts were effective for MC-LR degradation under UV-A and solar irradiation, whereas under vis irradiation only $\mathrm{N}$-modified $\mathrm{TiO}_{2}$ was active. Recently, co-modified $\mathrm{TiO}_{2}$ nanocatalysts have attracted significant attention because they possess a superior 
photocatalytic efficiency compared to single-modified $\mathrm{TiO}_{2}[1,40,42-45,47-50]$. However, there are only a few reports focusing on the photodegradation of MC-LR over mesoporous $\mathrm{A} / \mathrm{B} \mathrm{TiO}_{2}$ nanoparticles. In our previous reports, non-metal co-modified mesoporous anatase/brookite $\mathrm{TiO}_{2}$ was prepared and used for photocatalytic degradation of cyanotoxins and pharmaceuticals $[1,40,47,48]$. For example, $\mathrm{C} / \mathrm{N}$-co-modified mesoporous anatase/brookite $\mathrm{TiO}_{2}$ photocatalysts were highly active for MC-LR degradation under vis irradiation [1]. The impacts of initial $\mathrm{pH}$ value, the $\mathrm{TiO}_{2}$ content, and $\mathrm{MC}$-LR concentration on the photocatalytic activity were also investigated. It was found that the complete degradation $(100 \%)$ of MC-LR $\left(10 \mathrm{mg} \mathrm{L}^{-1}\right)$ was achieved, using co-modified $\mathrm{TiO}_{2}\left(0.4 \mathrm{~g} \mathrm{~L}^{-1}\right)$ at $\mathrm{pH} 4$ under visible light irradiation. Continuously, in this study, a facile method based on tuning the phase content and surface area of bare $\mathrm{TiO}_{2}$ nanoparticles to improve the photocatalytic degradation of MC-LR was investigated. It was found that both pristine $\mathrm{TiO}_{2}$ (prepared at $\mathrm{pH} 10$ ), and $\mathrm{C} / \mathrm{N} / \mathrm{S}$ co-modified $\mathrm{TiO}_{2}$ (synthesized by a simple method in which the best $\mathrm{TiO}_{2}$ sample was calcined with thiourea) exhibited an efficient performance for the decomposition of MC-LR $\left(\mathrm{C}_{0}=10 \mathrm{mg} \mathrm{L}^{-1}, \mathrm{pH} 4\right)$ during only 15 and 60-min irradiation with UV-A and solar simulation, respectively. In addition, the non-metal co-modified $\mathrm{TiO}_{2}$ showed $4 \times$ higher photocatalytic activity than bare $\mathrm{TiO}_{2}$ for MC-LR degradation during $3 \mathrm{~h}$-vis irradiation.

\section{Results and Discussion}

\subsection{Characterization of $\mathrm{TiO}_{2}$ Photocatalysts}

Six titania samples were used in this study, i.e., five non-modified samples (named as S1, S2, S3, S4 and S5) and one C/N/S-co modified sample (S4 modified with carbon, nitrogen and sulphur; named as CNS-S4). Phase structure and morphology (X-ray diffraction (XRD), and field emission scanning electron microscopy (FE-SEM); Figures 1 and 2), textural properties (specific surface area and particle size; Table 1), absorption properties (ultraviolet-visible diffuse reflectance spectroscopy (DRS); Figure 3), surface chemical characterization (X-ray photoelectron spectroscopy (XPS); Figure 4), and the photoluminescence $(\mathrm{PL})$ properties of the samples were investigated. The preparation conditions, phase composition, crystallite size, specific surface area, particle size, absorption edge, and band gap of the samples are summarized in Table 1.

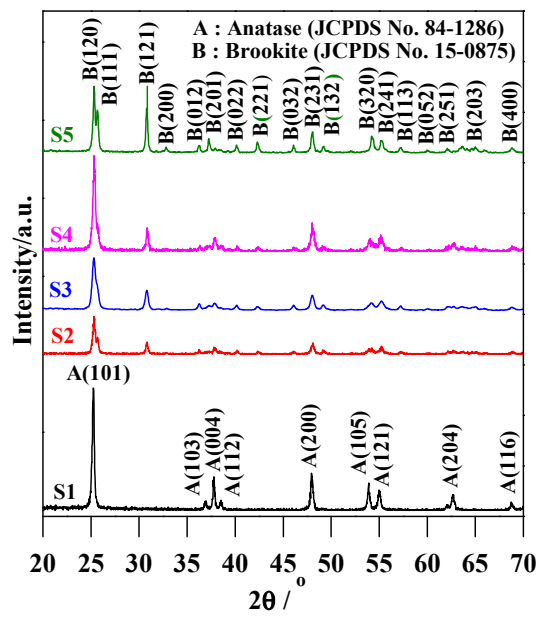

(a)

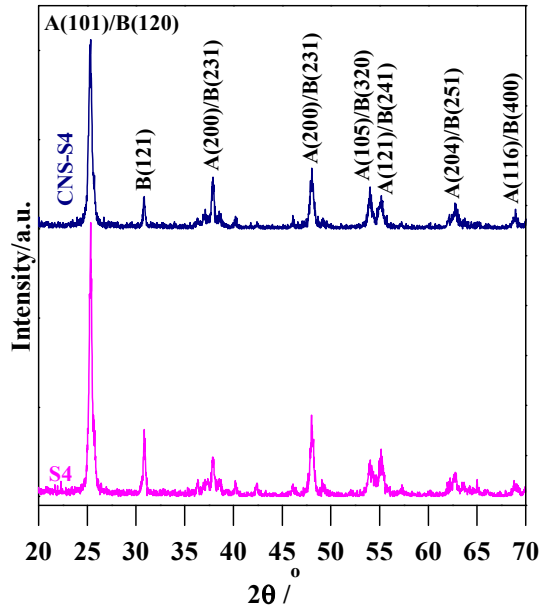

(b)

Figure 1. XRD patterns of: (a) S1, S2, S3, S4 and S5; and (b) S4 and CNS-S4. 


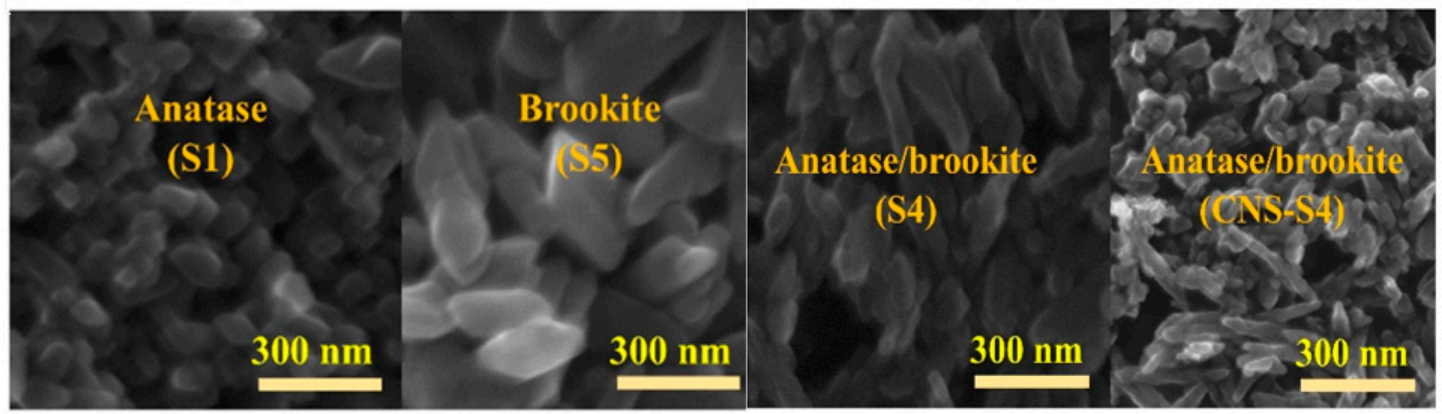

(a)

(b)

(c)

(d)

Figure 2. FE-SEM images of: (a) S1; (b) S5; (c) S4; and (d) CNS-S4.

Table 1. Preparation conditions, phase composition, crystal size, specific surface area, particle size, absorption edge and band gap of S1, S2, S3, S4, S5 and CN/S-S4 catalysts.

\begin{tabular}{|c|c|c|c|c|c|c|c|c|c|c|}
\hline \multirow{2}{*}{$\begin{array}{l}\text { Sample } \\
\text { Code }\end{array}$} & \multicolumn{2}{|c|}{$\begin{array}{l}\text { Preparation } \\
\text { Conditions }\end{array}$} & \multicolumn{2}{|c|}{$\begin{array}{c}\text { Phase } \\
\text { Composition }\end{array}$} & \multicolumn{2}{|c|}{$\begin{array}{c}\text { Crystal Size } \\
(\mathrm{nm})\end{array}$} & \multirow{2}{*}{$\begin{array}{l}\text { Specific Surface } \\
\text { Area }\left(\mathrm{m}^{2} \mathrm{~g}^{-1}\right)\end{array}$} & \multirow{2}{*}{$\begin{array}{l}\text { Pore Size } \\
\quad(\mathrm{nm})\end{array}$} & \multirow{2}{*}{$\begin{array}{c}\text { Absorption } \\
\text { Edge (nm) }\end{array}$} & \multirow{2}{*}{$\begin{array}{c}\text { Band Gap } \\
(\mathrm{eV})\end{array}$} \\
\hline & $\begin{array}{c}\text { Initial } \\
\mathrm{pH}\end{array}$ & $\begin{array}{l}\text { Modification } \\
\text { Source }\end{array}$ & $\mathbf{A} \%$ & $\mathbf{B} \%$ & $\mathbf{A}$ & B & & & & \\
\hline S1 & 3 & - & 100 & 0 & 29.6 & - & 28.0 & 1.12 & 375 & 3.23 \\
\hline S2 & 5 & - & 72.1 & 27.9 & 27.1 & 47.4 & 55.3 & 1.42 & 385 & 3.20 \\
\hline S3 & 7 & - & 65.7 & 34.3 & 25.7 & 46.8 & 60.1 & 1.45 & 389 & 3.18 \\
\hline S4 & 10 & - & 61.8 & 38.2 & 24.8 & 46.0 & 62.3 & 34.5 & 399 & 3.17 \\
\hline S5 & 11 & - & 0 & 100 & - & 52.3 & 23.4 & 1.48 & 374 & 3.30 \\
\hline CNS-S4 & 10 & thiourea & 70.6 & 27.4 & 28.3 & 48.2 & 30.0 & 2.4 & 420 & 2.90 \\
\hline
\end{tabular}

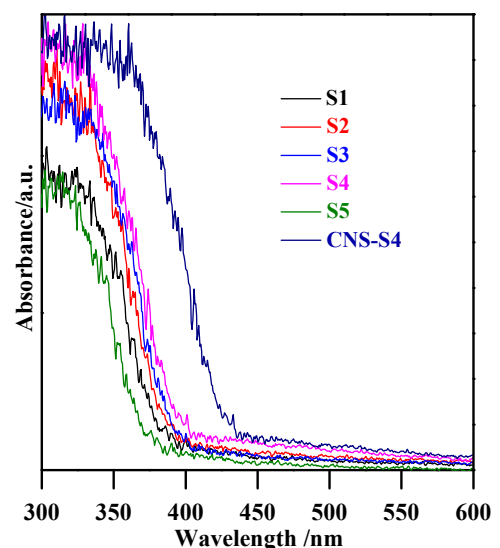

(a)

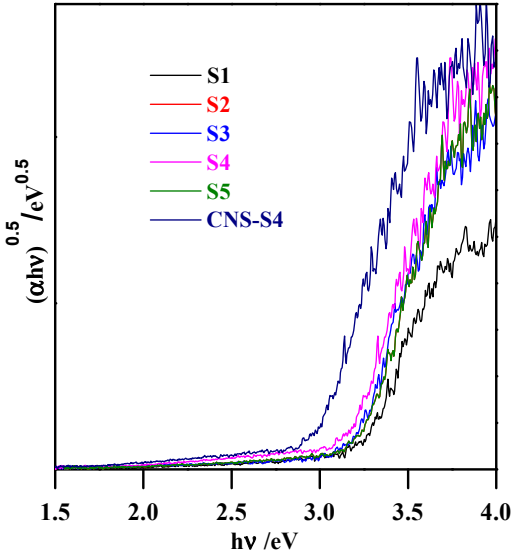

(b)

Figure 3. (a) diffuse reflectance spectra of S1, S2, S3, S4, S5 and CNS-S4; (b) curves of $(\alpha \mathrm{h} v)^{0.5}$ versus hv.

The XRD spectra revealed that the preparation $\mathrm{pH}$ value (i.e., glycine/ $\mathrm{NaOH}$ volume ratio) controlled the phase structure. The single-phase anatase (A) and brookite (B) were formed at $\mathrm{pH} 3$ and 11, respectively, whereas, with $\mathrm{pH}$ value ranging from 5 to $10, \mathrm{~A} / \mathrm{B}$-mixed-phase $\mathrm{TiO}_{2}$ powders were formed with a decrease in the anatase content through increasing the $\mathrm{pH}$ value (see Figure $1 \mathrm{a}$ and Table 1). Moreover, the phase structure did not change by non-metal modification, whereas the phase composition changed (anatase content increased), as shown in Figure $1 \mathrm{~b}$ and Table 1 . The crystalline size of anatase and brookite decreased within increasing of $\mathrm{pH}$ values (see Table 1). The specific surface area increased with increasing $\mathrm{pH}$ value till $\mathrm{pH} 10$, and then decreased at $\mathrm{pH} 11$ (Table 1). The co-modified $\mathrm{TiO}_{2}$ (CNS-S4) and non-modified (S4) possessed a mesoporous structure, whereas the microporous structure appeared in all other samples, as shown in Table 1. Figure 2a-c shows FE-SEM for S1, S4, S5 and CNS-S4 samples, indicating that the single-phase anatase and brookite contain nano-quasi-spherical-like, and nano-spindle-like particles, respectively. In contrast, the mixed-phase $\mathrm{TiO}_{2}$ contained nano-quasi-spherical-like anatase mixed with nano-rod-like brookite. As displayed by 
UV-Vis spectroscopy, the absorption was red-shifted for the co-modified sample, reflecting that the band gap value decreased from 3.17 to $2.9 \mathrm{eV}$ by non-metal modification (see Figure 3 and Table 1). The XPS spectroscopy revealed that the CNS-S4 sample was modified with C, N, and S $(20.78 \% \mathrm{Ti}$, $58.47 \% \mathrm{O}, 16.41 \% \mathrm{C}, 2.5 \% \mathrm{~S}$ and $1.84 \% \mathrm{~N}$ ), while the $\mathrm{S} 4$ sample was non-modified $\mathrm{TiO}_{2}$ (see Figure 4 ). Figure $4 \mathrm{a}$ shows the XPS survey spectra for S4 and CNS-S4 samples. Figure 4b displays an XPS spectrum of CNS-S4 for C 1s. Three peaks were observed with binding energies of 284.8, 286.5, and $289 \mathrm{eV}$, which were ascribed to $\mathrm{C}-\mathrm{O}$ and $\mathrm{C}=\mathrm{O}, \mathrm{O}=\mathrm{C}-\mathrm{O}$, Ti-O-C, and $\mathrm{C}-\mathrm{N}$ bonds ( 289 and $286.5 \mathrm{eV}$ ), and $\mathrm{C}-\mathrm{C}$ and $\mathrm{C}-\mathrm{H}$ bonds $(284.8 \mathrm{eV})[1,40,42,43,45,47,48]$. One peak with binding energy of $401 \mathrm{eV}$ was obtained for nitrogen ( $\mathrm{N}$ 1s), which was attributed to interstitial N-doping (Ti-O-N and Ti-N-O linkage), substitutional $\mathrm{N}$-doping (O-Ti-N linkage), hyponitrite species, and chemisorbed $\mathrm{N}$ species $\left(\mathrm{NO}, \mathrm{N}_{2} \mathrm{O}\right.$, $\mathrm{NO}^{2-}$, and $\mathrm{NO}^{3-}$ ) (see Figure 4c) [1,28,34,40-45,47,48,50]. Figure 4d gives XPS spectrum of CNS-S4 for sulphur (S 2p) with binding energy of $168.6 \mathrm{eV}$, which might be assigned to $\mathrm{S}^{6+} 2 \mathrm{P}_{3 / 2}[40,42,45,46,48]$. The substitution of $\mathrm{Ti}^{4+}$ by $\mathrm{S}^{6+}$ is much easier and more favorable than the replacement of $\mathrm{O}^{2-}$ with $\mathrm{S}^{2-}[40,48]$.

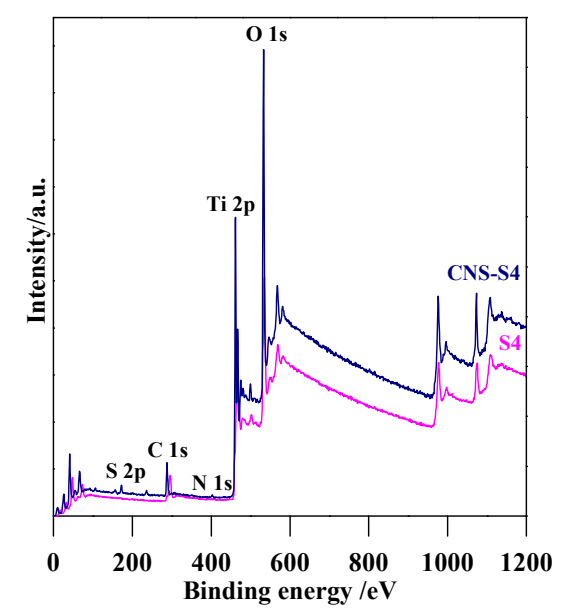

(a)

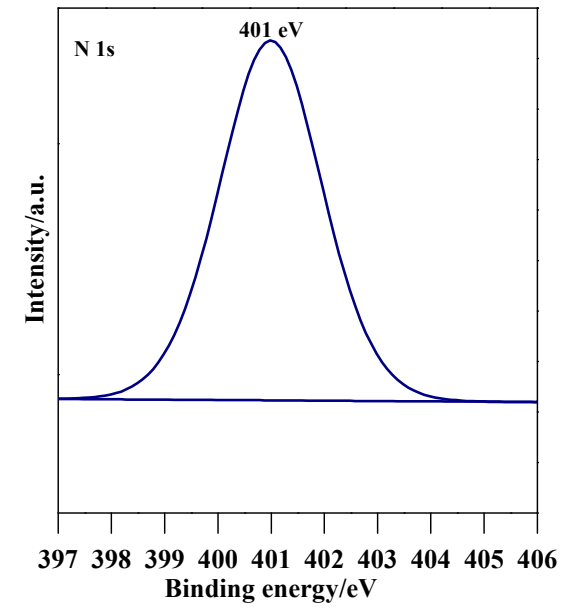

(c)

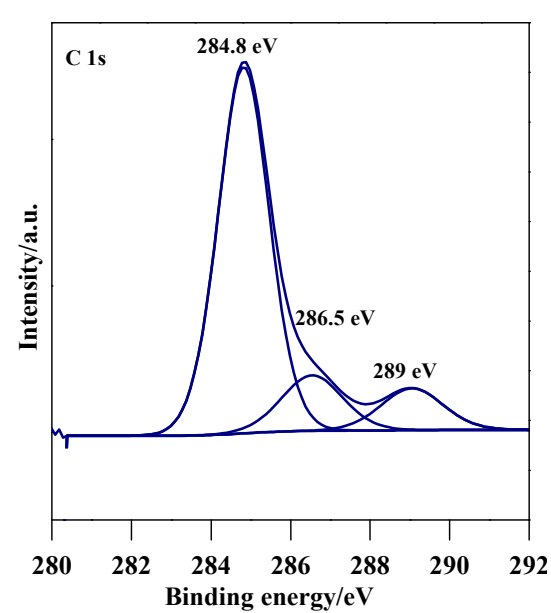

(b)

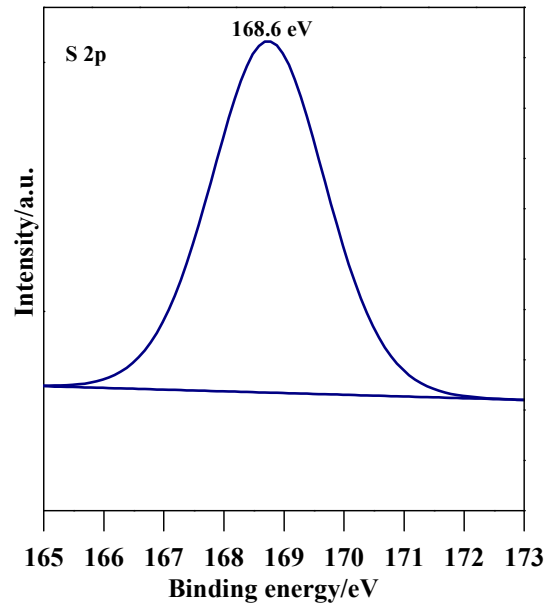

(d)

Figure 4. (a) XPS survey spectra for S4 and CNS-S4, and detailed scan in the energy regions of: (b) C $1 \mathrm{~s} ;$ (c) N 1s; and (d) S 2p of CNS-S4.

\subsection{Removal of MC-LR by Adsorption and Photolysis}

The experiments of MC-LR removal in the dark (absence of light) were conducted to determine the extent of MC-LR adsorption on the $\mathrm{TiO}_{2}$ surface. Figure $5 \mathrm{a}$ shows the change in MC-LR concentration vs. adsorption time in the presence of non-modified $\mathrm{TiO}_{2}(\mathrm{~S} 1, \mathrm{~S} 2, \mathrm{~S} 3, \mathrm{~S} 4$, and S5), and non-metal-co-modified 
$\mathrm{TiO}_{2}$ (CNS-S4) catalysts. It was indicated that 3-h stirring resulted in $41 \%, 39 \%, 25 \%, 18 \%, 16 \%$, and $14 \%$ adsorption of MC-LR on the surface of CNS-S4, S4, S3, S2, S1, and S5, respectively (see Figure 5). More efficient MC-LR adsorption on the surface of non-metal co-modified $\mathrm{TiO}_{2}$ sample (CNS-S4) compared to the non-modified samples (Figure 5) might result from either the non-metals presence or mesoporous structure, which act as active sites for pollutants adsorption and hence improves the adsorption capacity [51-55]. Among the non-modified $\mathrm{TiO}_{2}$, the $\mathrm{S} 4$ catalyst possessed the highest adsorption capacity because of its largest specific surface area (see Figure 6a).

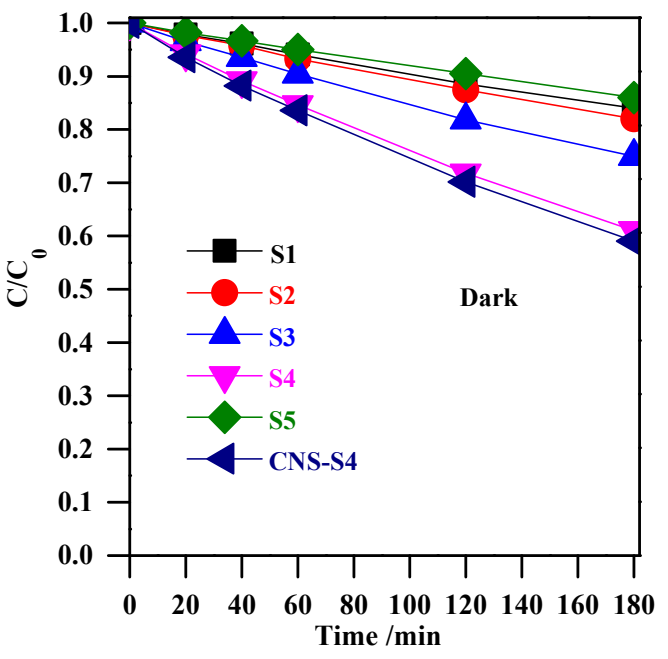

(a)

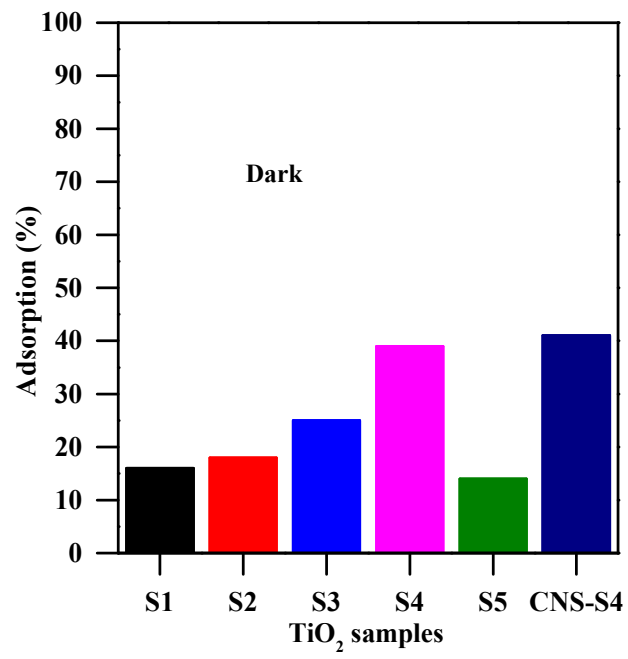

(b)

Figure 5. (a) change of the MC-LR concentration during stirring in the dark; (b) adsorption (\%) for MC-LR on the surface of S1, S2, S3, S4, S5, and CNS-S4. Catalyst loading, $0.4 \mathrm{~g} \mathrm{~L}^{-1}$; MC-LR dose, $10 \mathrm{mg} \mathrm{L}^{-1} ; \mathrm{pH}, 4 ; \mathrm{T}, 25^{\circ} \mathrm{C}$; reaction volume $40 \mathrm{~mL}$.

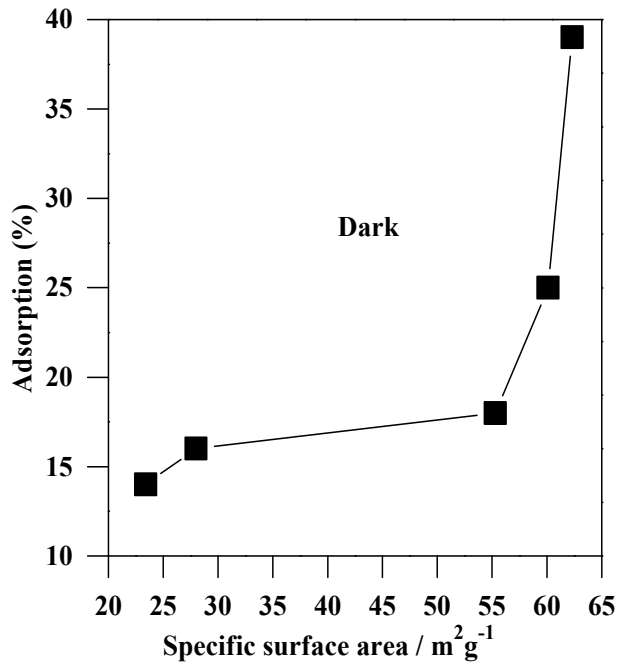

(a)

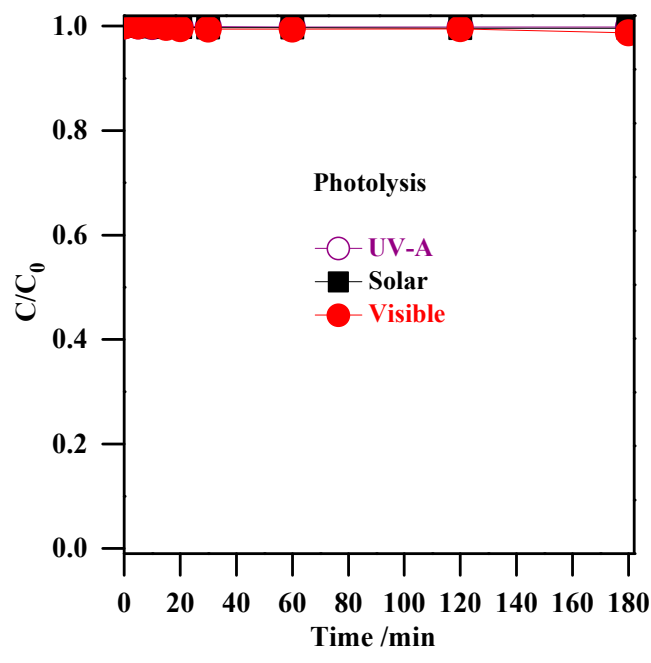

(b)

Figure 6. (a) correlation between the adsorption (\%) and the specific surface areas of S1, S2, S3, S4 and S5 samples; (b) MC-LR photolysis by UV-A, solar and visible irradiation.

The direct photolysis experiments of MC-LR by UV-A, solar, and visible irradiation were carried out (after obtaining adsorption equilibrium) in an aqueous solution (Figure $6 \mathrm{~b}$ ). It was found that the MC-LR degradation by photolysis was negligible, indicating that MC-LR could not easily be removed by irradiation alone, whether UV, solar, or visible. Indeed, many reports demonstrated the radiation alone (UV, solar and visible) is not effective for elimination of MC-LR [1,3,26-28,56-64]. From the 
above results, it was concluded that a more efficient method should be applied for MC-LR degradation, e.g., the photocatalysis (photocatalyst + light).

\subsection{Photocatalytic Degradation of MC-LR under UV-A, Solar and Visible Light}

The photocatalytic activity of the obtained $\mathrm{TiO}_{2}$ photocatalysts was evaluated by photodegradation of MC-LR under UV-A, solar and visible light (Figures 7-10). Firstly, the discussion will focus on the photocatalytic degradation of MC-LR under UV-A and solar irradiation (Figures 7 and 8). It was found that the mixed-phase $\mathrm{TiO}_{2}$ photocatalysts (S2, S3 and S4) were more efficient than single-phase ones (S1 and S5) toward degradation of MC-LR under UV-A (Figure 7a) and solar light (Figure 8a). The efficiency of MC-LR photodegradation under UV-A using the S4, S3, and S2 photocatalysts reached $97 \%, 94 \%$ and $68 \%$, respectively, whereas only $46 \%$ and $41 \%$ were achieved in the presence of $\mathrm{S} 1$ and S5 photocatalysts, respectively (Figure 7c, and Table 2). The photocatalytic efficiencies of S1, S2, S3, S4 and S5 toward MC-LR degradation under solar light were slightly lower resulting in 55\%, 67\%, $87 \%, 99 \%$ and $37 \%$, respectively (see Figure 8 , and Table 2). The complete MC-LR degradation $(100 \%)$ was achieved under both UV-A and solar irradiation using only co-modified $\mathrm{TiO}_{2}(\mathrm{CNS}-\mathrm{S} 4)$ sample (Figures 7a and $8 \mathrm{a}$, and Table 2). The kinetic analysis (by plotting the natural logarithm of MC-LR concentration versus time, Figures $7 \mathrm{~b}$ and $8 \mathrm{~b}$ ) indicates the first-order reaction, which is typical for photocatalytic decomposition of various organic compounds $[1,14,31,34,39,40,43,45,48]$. The estimated reaction rate constant (K) for S1, S2, S3, S4, S5 and CNS-S4 samples under UV-A irradiation were 0.041, $0.076,0.196,0.238,0.035$ and $0.257 \mathrm{~min}^{-1}$ (Figure $7 \mathrm{~b}$, and Table 2), respectively, whereas, under solar irradiation, 2-6× smaller constants were obtained, i.e., $0.013,0.019,0.034,0.082,0.008$ and $0.106 \mathrm{~min}^{-1}$ (Figure $8 \mathbf{b}$, and Table 2), respectively. The smaller reaction rate constants under solar irradiation than that under UV-A results from inactivity of bare titania under vis irradiation (main part of solar simulator emission). The corresponding reaction rates followed the order of CNS-S4 $>\mathrm{S} 4>\mathrm{S} 3>\mathrm{S} 2>$ S1 > S5 reaching $21.6 \times 10^{-4}$ and $8.90 \times 10^{-4} \mathrm{mmol} \mathrm{L}^{-1} \mathrm{~min}^{-1}, 20.2 \times 10^{-4}$ and $7.01 \times 10^{-4} \mathrm{mmol} \mathrm{L}^{-1}$ $\min ^{-1}, 17.1 \times 10^{-4}$ and $3.11 \times 10^{-4} \mathrm{mmol} \mathrm{L}^{-1} \mathrm{~min}^{-1}, 7.1 \times 10^{-4}$ and $1.81 \times 10^{-4} \mathrm{mmol} \mathrm{L}^{-1} \mathrm{~min}^{-1}, 3.9 \times$ $10^{-4}$ and $1.20 \times 10^{-4} \mathrm{mmol} \mathrm{L}^{-1} \mathrm{~min}^{-1}$, and $3.3 \times 10^{-4}$ and $0.76 \times 10^{-4} \mathrm{mmol} \mathrm{L}^{-1} \mathrm{~min}^{-1}$ under UV-A (Figure 7c) and solar irradiation (Figure 8c), respectively.

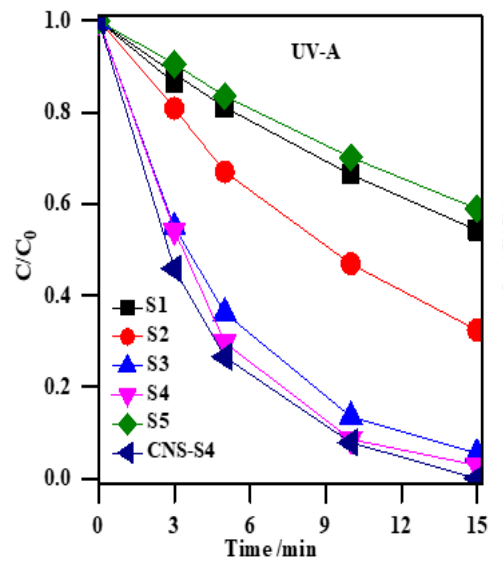

(a)

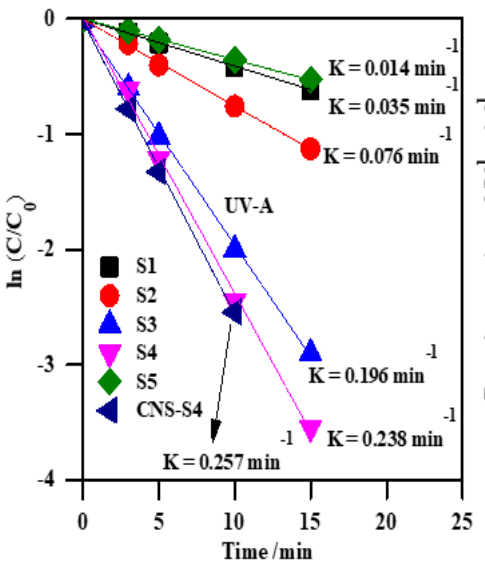

(b)

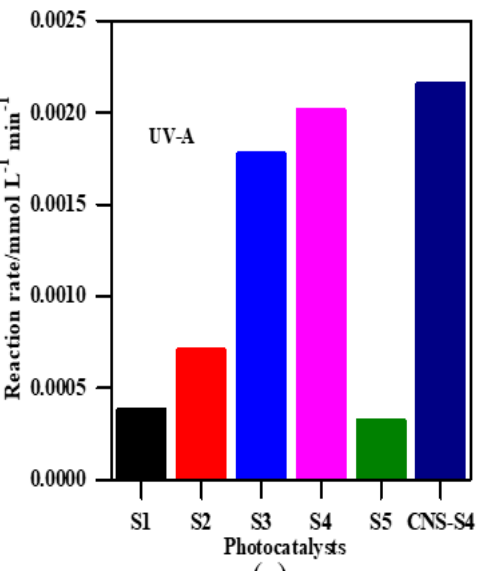

(c)

Figure 7. (a) change of the MC-LR concentration during irradiation; (b) plot of $\ln \left(\mathrm{C} / \mathrm{C}_{0}\right)$ versus irradiation time; (c) comparison of the degradation rate of MC-LR using S1, S2, S3, S4, S5, and CNS-S4 photocatalysts under UV-A light. Catalyst loading, $0.4 \mathrm{~g} \mathrm{~L}^{-1}$; MC-LR dose, $10 \mathrm{mg} \mathrm{L}^{-1}$; $\mathrm{pH}, 4$; $\mathrm{T}, 25^{\circ} \mathrm{C}$; reaction volume $40 \mathrm{~mL}$. 


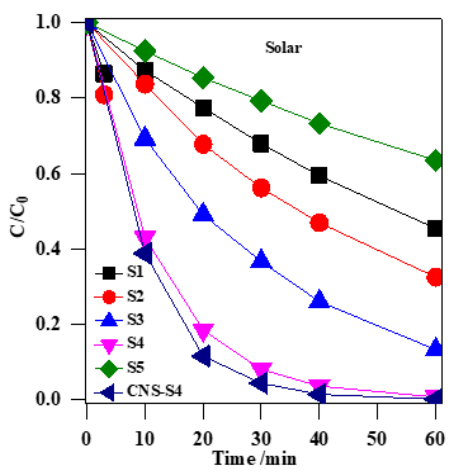

(a)

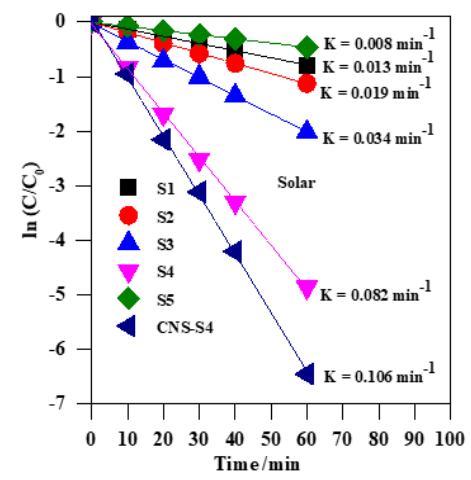

(b)

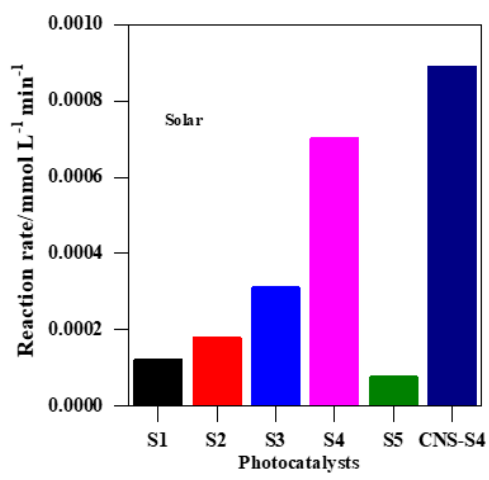

(c)

Figure 8. (a) change of the MC-LR concentration during irradiation with solar simulation; (b) plot of $\ln \left(\mathrm{C} / \mathrm{C}_{0}\right)$ versus irradiation time; (c) comparison of the degradation rate of MC-LR using S1, S2, S3, S4, S5 and CNS-S4 photocatalysts under solar irradiation. Catalyst loading, $0.4 \mathrm{~g} \mathrm{~L}^{-1}$; MC-LR dose, $10 \mathrm{mg} \mathrm{L}^{-1}$; $\mathrm{pH}, 4 ; \mathrm{T}, 25^{\circ} \mathrm{C}$; reaction volume $40 \mathrm{~mL}$.

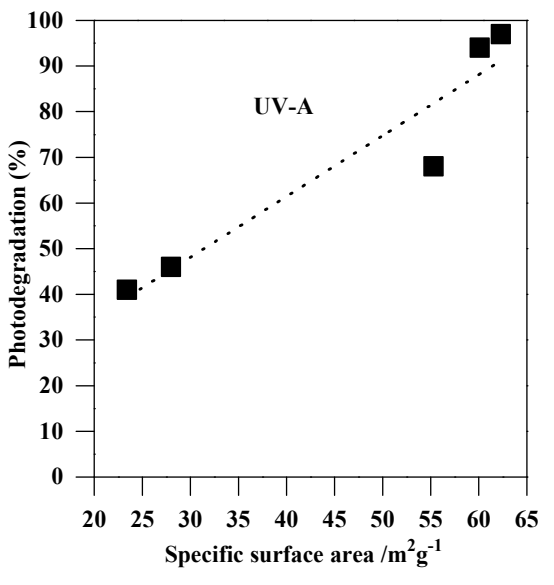

(a)

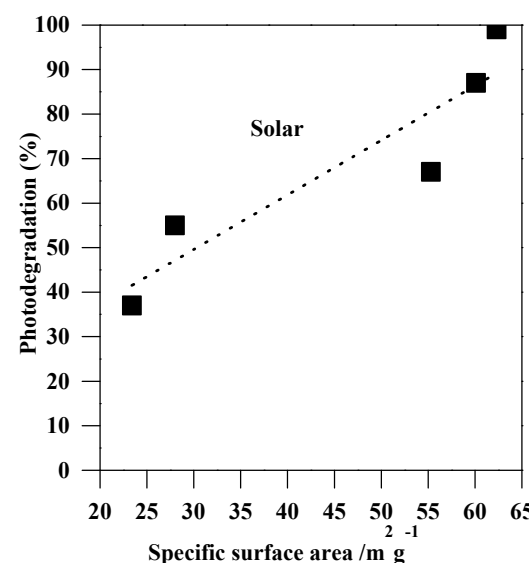

(b)

Figure 9. Correlation between the photodegradation efficiency (\%) and the specific surface areas of the non-modified $\mathrm{TiO}_{2}$ photocatalysts: (a) under UV-A; and (b) under solar irradiation.

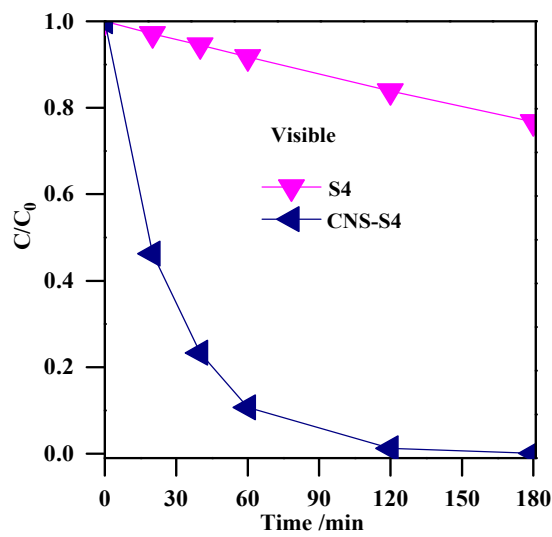

(a)

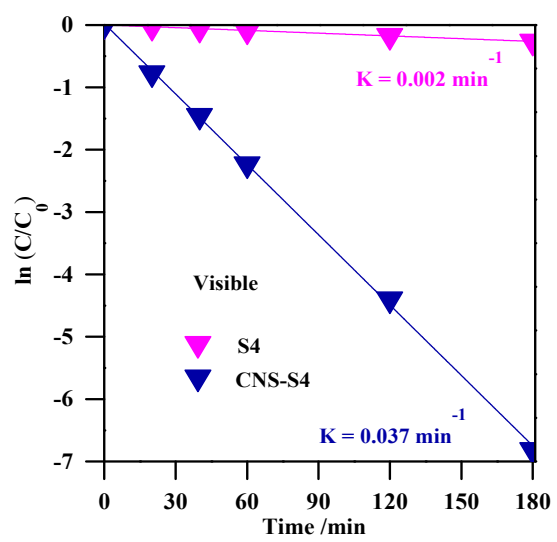

(b)

Figure 10. (a) change of the MC-LR concentration during visible light irradiation; (b) plot of $\ln \left(\mathrm{C} / \mathrm{C}_{0}\right)$ versus irradiation time. Photocatalyst loading (S4, CNS-S4), $0.4 \mathrm{~g} \mathrm{~L}^{-1}$; MC-LR dose, $10 \mathrm{mg} \mathrm{L}-1$; $\mathrm{pH}, 4$; $\mathrm{T}, 25^{\circ} \mathrm{C}$; reaction volume $40 \mathrm{~mL}$. 
Table 2. The reaction rate constant $(\mathrm{K})$, specific surface area $\left(\mathrm{S}_{\mathrm{BET}}\right)$, reaction rate constant normalized by surface area, photodegradation efficiency, and $\mathrm{R}^{2}$ for bare $\mathrm{TiO}_{2}$ samples (S1, S2, S3, S4, and S5).

\begin{tabular}{|c|c|c|c|c|c|}
\hline \multicolumn{6}{|c|}{ UVA } \\
\hline Sample Code & $K\left(\min ^{-1}\right)$ & $S_{\text {BET }}\left(m^{2} g^{-1}\right)$ & $\begin{aligned} \mathrm{K} / \mathrm{S}_{\mathrm{BET}} & \left(\mathrm{g} \mathrm{min}^{-1} \mathrm{~m}^{-2}\right) \\
\times 10^{-3} & \end{aligned}$ & $\begin{array}{l}\text { Degradation } \\
\text { Efficiency (\%) }\end{array}$ & $\mathbf{R}^{2}$ \\
\hline S1 & 0.041 & 28.0 & 1.46 & 46 & \\
\hline S2 & 0.076 & 55.3 & 1.37 & 68 & \\
\hline S3 & 0.196 & 60.1 & 3.26 & 94 & 0.999 \\
\hline S4 & 0.238 & 62.3 & 3.82 & 97 & \\
\hline S5 & 0.035 & 23.4 & 1.50 & 41 & \\
\hline \multicolumn{6}{|c|}{ Solar } \\
\hline Sample Code & $K\left(\min ^{-1}\right)$ & $S_{\text {BET }}\left(m^{2} g^{-1}\right)$ & $\begin{aligned} & \mathrm{K} / \mathrm{S}_{\text {BET }}\left(\mathrm{g} \mathrm{min}^{-1} \mathrm{~m}^{-2}\right) \\
& \times 10^{-4}\end{aligned}$ & $\begin{array}{l}\text { Degradation } \\
\text { Efficiency (\%) }\end{array}$ & $\mathbf{R}^{2}$ \\
\hline S1 & 0.013 & 28.0 & 4.64 & 55 & \\
\hline $\mathrm{S} 2$ & 0.019 & 55.3 & 3.44 & 67 & \\
\hline S3 & 0.034 & 60.1 & 5.66 & 87 & 0.999 \\
\hline $\mathrm{S} 4$ & 0.082 & 62.3 & 1.32 & 99 & \\
\hline S5 & 0.008 & 23.4 & 3.42 & 37 & \\
\hline
\end{tabular}

The remarkable photocatalytic performance of S4 (among the non-modified samples) and CNS-S4 (among all samples) might be explained by the phase structure and composition (S4 and CNS-S4), mesoporous structure (S4 and CNS-S4), high specific surface area (S4), and non-metal co-modification (CNS-S4) [1,14,28,31,34,36-51,53-55]. Both S4 and CNS-S4 contained anatase/brookite mixed-phase, and this might result in efficient separation of charge carriers by their possible migration between two phases (PL; Figure 11) [1,31,36-40,47,48]. The mesoporous structure of both S4 and CNS-S4 is also favorable for efficient activity because of providing more active sites on $\mathrm{TiO}_{2}$ surface, the accumulation of hydroxyl radicals inside the mesopores, high dispersion of mesoporous $\mathrm{TiO}_{2}$ in the aqueous solution, and rapid diffusion of MC-LR to the active sites on the surface of the mesoporous $\mathrm{TiO}_{2}$ photocatalyst (as also proved by high adsorption ability) $[1,31,39,40,47,48,65,66]$. More efficient adsorption and degradation of MC-LR under UV-A and solar light over the S4 sample than that on the other non-modified $\mathrm{TiO}_{2}$ samples could result from larger specific surface area, as shown in Figure 9. In order to correct the photocatalytic activity of bare $\mathrm{TiO}_{2}$ samples (S1, S2, S3, S4, and S5) considering the surface area, the reaction rate constant was normalized by a specific surface area and summarized in Table 2. The highest photocatalytic degradation rate and normalized reaction rate constant, based on surface area, were observed for the S4 sample (with the highest surface area). Therefore, it was concluded that the surface area can play an important role in the photocatalytic degradation of MC-LR. Higher surface area introduces more active sites on the photocatalyst surface, enhancing the adsorption of organic pollutants, and it might also lead to a high concentration of surface hydroxyl groups, which can trap the photogenerated holes and thus decrease the electron-hole recombination, as demonstrated by PL results (see Figure 11) $[1,31,39,40,47,66]$. From the above results and discussion, it is reasonable to hypothesize that the preparation $\mathrm{pH}$ value is a key factor that affects directly the photocatalytic activity of the $\mathrm{TiO}_{2}$ nanoparticles. Indeed, it is known that the $\mathrm{pH}$ value might control the surface characteristics and the size of aggregated nanoparticles resulting in higher content of formed hydroxyl radicals, and improved adsorption capacity of organic pollutants onto a photocatalysts surface [67]. Therefore, our results demonstrating the role of preparation $\mathrm{pH}$ value for controlling of the phase composition and boosting the photocatalytic activity of $\mathrm{TiO}_{2}$ nanoparticles is consentient with previous reports $[68,69]$. It was also proposed that the highest activity of the co-modified $\mathrm{TiO}_{2}$ photocatalyst (CNS-S4) results from a non-metals presence, which could act as active sites for efficient MC-LR adsorption and degradation [51-55]. It is known that non-metal modification 
is responsible for the increase of superficial hydroxyl groups' content and faster electron transfer, and thus higher photocatalytic activity $[1,14,28,42-45,47]$.

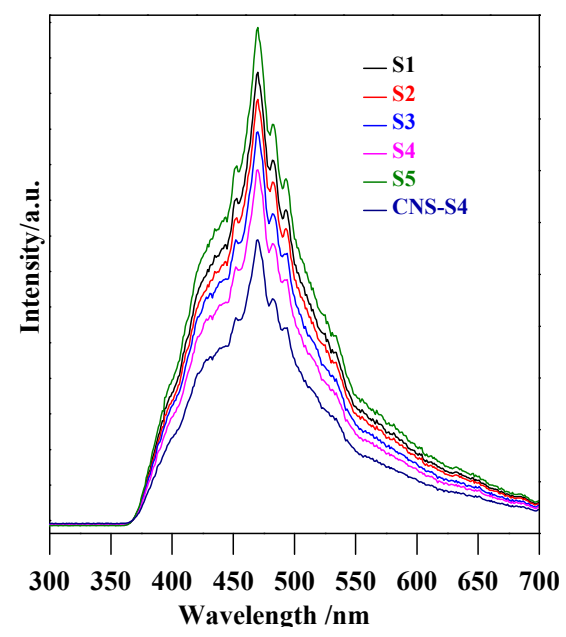

Figure 11. PL spectra of S1, S2, S3, S4, and CNS-S4 samples.

Although the results clearly showed much higher activity of CNS-S4 than other samples under solar irradiation, the reason could not be unequivocally decided, i.e., favorable surface properties, best phase composition $(\mathrm{A} / \mathrm{B}=2.5)$ or non-metal presence. Therefore, the photodegradation experiments under visible light irradiation were performed for two samples of the highest activity (S4 and CNS-S4), and obtained results are shown in Figure 10a. It was found that the non-modified $\mathrm{TiO}_{2}$ photocatalyst, which could absorb only UV light $(\lambda<400 \mathrm{~nm})$, was almost inactive $(<25 \%)$ under visible light irradiation, and this low MC-LR degradation might be assigned to slight light transmittance below the wavelength of $420 \mathrm{~nm}[3,28]$. In contrast, MC-LR was completely degraded after 180-min stirring under visible light irradiation in the presence of C/N/S-co-modified $\mathrm{TiO}_{2}$ (CNS-S4), as shown in Figure 10a. Similar to degradation under UV-A and solar irradiation, photocatalytic degradation of MC-LR followed first-order kinetics, as shown in Figure 10b. The rate constants and reaction rates were: $\mathrm{K}=0.002 \mathrm{~min}^{-1}, r=0.170 \times 10^{-4} \mathrm{mmol} \mathrm{L}^{-1} \mathrm{~min}^{-1}$ and $\mathrm{K}=0.037 \mathrm{~min}^{-1}, r=3.2 \times 10^{-4} \mathrm{mmol} \mathrm{L}^{-1}$ $\mathrm{min}^{-1}$ for S4 and CNS-S4 photocatalysts, respectively. Therefore, it was proposed that the structure and specific surface area were not the reasons for the remarkable photocatalytic activity of CNS-S4 sample under visible light irradiation. It should be pointed that these two samples possessed almost the same morphology, i.e., nano-rod-like brookite with nano-quasi-spherical-like anatase (see FE-SEM images: Figure 2c,d). In addition, although the specific surface area of CNS-S4 $\left(30.00 \mathrm{~m}^{2} \mathrm{~g}^{-1}\right)$ was two times lower than that of S4 $\left(62.3 \mathrm{~m}^{2} \mathrm{~g}^{-1}\right)$, the reaction rate of CNS-S4 was ca. $20 \times$ higher than that of S4. Therefore, it could be concluded that non-metal modification played a major role in enhancing the activity of CNS-S4 under the vis range of a solar spectrum, as clearly indicated from sample characteristics. It was proposed that the $\mathrm{O} 2 \mathrm{p}$ orbitals of $\mathrm{TiO}_{2}$ could overlap with orbitals of $\mathrm{C}, \mathrm{N}$ and $\mathrm{S}$, forming mid-gap levels between conduction band (CB) and valence band (VB), and thus narrowing the bandgap of CNS-S4 [40,45,47,48,50]. Additionally, the carbonaceous species, which may act as a photo-sensitizer like organic dyes, might be formed on the surface of $\mathrm{TiO}_{2}$ by carbon modification [70], whereas nitrogen might convert some $\mathrm{Ti}^{4+}$ to $\mathrm{Ti}^{3+}$ by charge compensation, and thus form donor energy levels below the conduction band [71]. The $\mathrm{O} 2 \mathrm{p}$ of $\mathrm{TiO}_{2}$ could be substituted by nitrogen atoms to form isolated impurity energy levels above the valence band [70]. The photoluminescence (PL) is often a useful tool for investigating separation/recombination of photogenerated charges in semiconductors since the PL emission intensity is related directly to the electron-hole recombination rate. Lower PL emission intensities correspond to more efficient electron-hole separation and hence improve the photocatalytic activity of the photocatalyst $[1,47,48]$. In order to reveal the superior catalytic activity of $\mathrm{S} 4$ and CNS-S4 compared to the rest of the bare $\mathrm{TiO}_{2}$ samples (S1, S2, S3, and S5), the PL spectra 
with excitation wavelength of $300 \mathrm{~nm}$, for all samples were conducted, and the results are shown in Figure 11. It was found that the PL spectra peaks of all samples are around $470 \mathrm{~nm}$ with different intensities, which decrease in the following order: CNS-S4 $<\mathrm{S} 4<\mathrm{S} 3<\mathrm{S} 2<\mathrm{S} 1<\mathrm{S} 5$ (see Figure 11). The higher PL intensity of single-phase $\mathrm{TiO}_{2}(\mathrm{~S} 1$ (A), and $\mathrm{S} 5$ (B)) demonstrated their lower photocatalytic activity compared to mixed-phases $\mathrm{TiO}_{2}$ (S2, S3, S4, and CNS-S4). These findings could be explained by the fact that hole trapping by non-metals and synergistic effect between anatase and brookite might facilitate the electron-hole separation $[1,31,39,47,48]$.

\section{Materials and Methods}

\subsection{Materials}

Titanium(III) sulfate $\left(\mathrm{Ti}_{2}\left(\mathrm{SO}_{4}\right)_{3}\right.$, Fisher, Loughborough, Leicestershire, UK, $\left.15 \%\right)$, sodium nitrate $\left(\mathrm{NaNO}_{3}\right.$, Koch-light laboratories Ltd., Haverhill, Suffolk, UK, $\left.98 \%\right)$, glycine $\left(\mathrm{H}_{2} \mathrm{~N}-\mathrm{CH}_{2}-\mathrm{COOH}\right.$, Sigma-Aldrich, St. Louis, MO, USA, 99\%), sodium hydroxide ( $\mathrm{NaOH}$, LobaChemie, Pellets, Mumbai, India, 98\%), thiourea $\left(\mathrm{H}_{2} \mathrm{~N}-\mathrm{CS}-\mathrm{NH}_{2}\right.$, Sigma-Aldrich, Darmstadt, Germany, 99\%), MC-LR (Cal-Biochem, Nottingham, UK, $99 \%)$, and absolute ethanol $\left(\mathrm{CH}_{3} \mathrm{CH}_{2} \mathrm{OH}\right.$, Sigma-Aldrich, Darmstadt, Germany, $99.8 \%$ ) were used without any further purification. The water used for the experiment was deionized water $(\mathrm{DI}, 18.2 \mu \Omega)$.

\subsection{Preparation and Characterization of $\mathrm{TiO}_{2}$ Photocatalysts}

The preparation and characterization of non-modified $\mathrm{TiO}_{2}$, and $\mathrm{C} / \mathrm{N} / \mathrm{S}$-co-modified $\mathrm{TiO}_{2}$ were described in our previous works $[39,48]$. In short, to synthesize the non-modified $\mathrm{TiO}_{2}$, with different anatase/brookite ratios, the $\mathrm{NaNO}_{3}$ as an oxidizing agent was added to aqueous $\mathrm{Ti}_{2}\left(\mathrm{SO}_{4}\right)_{3}$ solution, and then stirred till formation of the colorless solution. After that, different volume ratios of glycine $/ \mathrm{NaOH}$ were added dropwise to the colorless solution resulting in different $\mathrm{pH}$ values. After stirring for $\sim 25 \mathrm{~min}$, the suspension was transferred into a 100-mL Teflon-lined tube and heated at $200{ }^{\circ} \mathrm{C}$ for $20 \mathrm{~h}$. Ultimately; the $\mathrm{TiO}_{2}$ catalyst was collected, rinsed several times with $\mathrm{DI}-\mathrm{H}_{2} \mathrm{O}$ and alcohol, and dried at $60{ }^{\circ} \mathrm{C}$. The samples prepared at different $\mathrm{pH}$ values of $3,5,7,10$ and 11 were named as $\mathrm{S} 1, \mathrm{~S} 2, \mathrm{~S} 3, \mathrm{~S} 4$ and $\mathrm{S} 5$, respectively.

The N/C/S-co-modified mesoporous $\mathrm{A} / \mathrm{B} \mathrm{TiO}_{2}$ photocatalyst was prepared by an ex-situ method. Shortly, the non-modified $\mathrm{A} / \mathrm{B}$ mixed-phase $\mathrm{TiO}_{2}$ powder (S4) was grounded with thiourea with a 1:1 weight ratio, and then put into a muffle furnace (Nabertherm with controller) and calcined at $450{ }^{\circ} \mathrm{C}$ for $1 \mathrm{~h}$. The obtained sample was washed several times and then dried at $60^{\circ} \mathrm{C}$ for $10 \mathrm{~h}$. The yellow powder was signed as CNS-S4.

The obtained $\mathrm{TiO}_{2}$ powders were characterized by various advanced methods, including X-ray diffraction (XRD, D8, Bruker AXS X-ray diffraction, Karlsruhe, Germany), field emission scanning electron microscopy (FE-SEM; QUANTAFEG 250, the Netherlands), specific surface area (SSA) measurements, ultraviolet-visible diffuse reflectance spectroscopy (UV-vis DRS, (UV-2501 PC, Shimadzu, Tokyo, Japan), and X-ray photoelectron spectroscopy (XPS, Thermo Fisher Scientific, Waltham, MA, USA).

\subsection{Photocatalytic Tests}

A stock aqueous solution of MC-LR (10 mg L $\left.{ }^{-1}\right)$ was prepared ( $\mathrm{pH}$ 6.3). Prior to the photocatalytic experiments, the standard calibration curve was made for MC-LR concentrations in the range of 5-30 $\mathrm{mg} \mathrm{L}^{-1}$. The photocatalytic degradation experiments were carried out in a double jacket round quartz reactor with a $50 \mathrm{~mL}$ volume. The temperature was maintained at $25^{\circ} \mathrm{C}$ by the circulation of thermostated water around the reactor. Firstly, an aqueous solution of MC-LR $(40 \mathrm{~mL})$ was added to a round quartz reactor containing $\mathrm{TiO}_{2}$ powder $\left(0.4 \mathrm{~g} \mathrm{~L}^{-1}\right)$, and sonicated to obtain a uniform suspension, and then the $\mathrm{pH}$ value was adjusted to be 4 . The reaction solution (MC-LR, $\mathrm{H}_{2} \mathrm{O}$, and $\mathrm{TiO}_{2} ; \mathrm{pH} 4$ ) was stirred for $180 \mathrm{~min}$ in the dark to achieve the adsorption equilibrium for MC-LR on 
the catalyst surface before starting the experiments. After that, the suspension was irradiated from the top by a UV-A lamp $\left(\lambda_{\max }=365 \mathrm{~nm}\right.$, intensity $\left.=2 \mathrm{~mW} \mathrm{~cm}^{-2}\right)$, solar simulator lamp (SOL1200 lamp, intensity $\left.=20 \mathrm{~mW} \mathrm{~cm}^{-2}\right)$, and visible-LED lamp $\left(\lambda_{\max }=420 \mathrm{~nm}\right.$, intensity $\left.=1 \mathrm{~mW} \mathrm{~cm}^{-2}\right)$. The samples were taken at different times, and then filtered using a $0.22-\mu \mathrm{m}$ filter membrane. The residual MC-LR concentration at different durations was analyzed using a high-performance liquid chromatography (HPLC, 1260, Agilent, Hamburg, Germany) with a G1311C-1260 Quat pump and a G1365D-1260 MWD UV detector (Hamburg, Germany), set at $238 \mathrm{~nm}$ with a C18 column (100 mm Long $\times 4.6 \mathrm{~mm}$ i.d., $3.5 \mu \mathrm{m}$ particles) by the method reported before [1,72]. The reaction rates were estimated and fitted with the Langmuir-Hinshelwood first-order kinetic model. The degradation rate $(r)$ was calculated using Equation (1) [1,12,31,40]:

$$
r=\mathrm{K} \times \mathrm{C}_{0}{ }^{\mathrm{n}},
$$

where $\mathrm{K}$ is the rate constant, $\mathrm{C}_{0}$ is the initial concentration of MC-LR, and $n$ is the order of the reaction.

The MC-LR photodegradation efficiencies (\%) using the prepared $\mathrm{TiO}_{2}$ photocatalysts under UV-A, solar and visible light were estimated using Equation $(2)[9,10]$ :

$$
\text { Photodegradation efficiency }(\%)=\left(1-\left(C / C_{0}\right)\right) \times 100 \text {, }
$$

where $\mathrm{C}_{0}$ and $\mathrm{C}$ are the MC-LR concentrations before and after irradiation, respectively.

\section{Conclusions}

The MC-LR toxin was removed from aqueous solution by UV-A, solar and visible light in the presence of nanostructured $\mathrm{TiO}_{2}$ photocatalysts (anatase, brookite, anatase-brookite, C/N/S-co-modified anatase-brookite). A simple hydrothermal method was investigated to synthesize pristine $\mathrm{TiO}_{2}$ nanoparticles with tunable $\mathrm{A} / \mathrm{B}$ ratios, which was achieved by changing the preparation $\mathrm{pH}$ value. In addition, the best bare $\mathrm{TiO}_{2}$ was calcined with thiourea to obtain $\mathrm{C} / \mathrm{N} / \mathrm{S}$-co-modified mesoporous $\mathrm{A} / \mathrm{B}$ $\mathrm{TiO}_{2}$. The effect of the preparation $\mathrm{pH}$ value on the phase composition, surface area, and photocatalytic activity was investigated, and $\mathrm{pH}$-dependent behavior was observed. It was found that the single-phase $\mathrm{TiO}_{2}$ nanoparticles, anatase and brookite, were formed at high acidic and basic $\mathrm{pH}$, respectively, and $\mathrm{A} / \mathrm{B} \mathrm{TiO}_{2}$ samples were obtained in the $\mathrm{pH}$ value range of 5 to 10 . Upon increasing the $\mathrm{pH}$, the specific surface areas increased, leading to higher photocatalytic activity. The co-modified and non-modified mixed-phases $\mathrm{TiO}_{2}$ exhibited a superior photocatalytic activity compared to the single-phase $\mathrm{TiO}_{2}$ (anatase and brookite) under UV-A and solar irradiation, probably because of mixed-phase formation, mesoporous structure, and higher specific surface area (non-modified mixed-phase $\mathrm{TiO}_{2}$ ). The non-modified $\mathrm{TiO}_{2}$ practically was inactive under visible light irradiation $(<25 \%)$, whilst the complete MC-LR degradation $(100 \%)$ was achieved in the presence of $\mathrm{C} / \mathrm{N} / \mathrm{S}$ co-modified- $\mathrm{TiO}_{2}$. It is proposed that this improved activity for co-modified $\mathrm{TiO}_{2}$ comes from non-metal-co-modification, resulting in bandgap narrowing. Hence, highly active photocatalysts against very toxic pollutants (MC-LR) could be efficiently applied for water/wastewater purification under natural solar radiation.

Author Contributions: Conceptualization, T.M.K., S.M.E.-S., and H.M.A.; methodology, T.M.K.; experimental research, T.M.K.; data analysis, T.M.K., S.M.E.-S., H.M.A., and E.K.; writing-original draft preparation, T.M.K.; writing-review and editing, T.M.K., S.M.E.-S., A.A.I., H.M.A., and E.K.; resources, D.W.B., S.M.E.-S., A.A.I., and E.K.; publication fees, E.K.; supervision, S.M.E.-S., H.M.A., A.A.I., E.K., and D.W.B.

Funding: This work was supported by the Egyptian Ministry of Higher Education (Cultural Affairs and Missions Sector). A part of this work was also supported by the US-Egypt Joint project Cycle 17 No. 229 and short-term fellowship Cycle 6, Science \& Technological Development Fund in Egypt (STDF-STF) under Grant No. 25503.

Acknowledgments: T.M.K. acknowledges the Institute of Technical Chemistry, Photocatalysis and Nanotechnology Research Unit, Leibniz Universität Hannover, Germany for hosting him during this research work.

Conflicts of Interest: The author declares no conflict of interest. 


\section{References}

1. Khedr, T.M.; El-Sheikh, S.M.; Ismail, A.A.; Kowalska, E.; Bahnemann, D.W. Photodegradation of Microcystin-LR Using Visible Light-Activated C/N-co-Modified Mesoporous $\mathrm{TiO}_{2}$ Photocatalyst. Materials 2019, 12, 1027. [CrossRef] [PubMed]

2. Chae, S.; Noeiaghaei, T.; Oh, Y.; Kim, I.S.; Park, J.-S. Effective removal of emerging dissolved cyanotoxins from water using hybrid photocatalytic composites. Water Res. 2019, 149, 421-431. [CrossRef] [PubMed]

3. Khadgi, N.; Upreti, A.R. Photocatalytic degradation of Microcystin-LR by visible light active and magnetic, $\mathrm{ZnFe}_{2} \mathrm{O}_{4}-\mathrm{Ag} / \mathrm{rGO}$ nanocomposite and toxicity assessment of the intermediates. Chemosphere 2019, 221, 441-451. [CrossRef] [PubMed]

4. Diez-Quijada, L.; Prieto, A.I.; Guzman-Guillen, R.; Jos, A.; Camean, A.M. Occurrence and toxicity of microcystin congeners other than MC-LR and MC-RR: A review. Food Chem. Toxicol. 2019, 125, $106-132$. [CrossRef]

5. Carmichael, W.W.; Azevedo, S.M.; An, J.S.; Molica, R.J.; Jochimsen, E.M.; Lau, S.K.; Rinehart, L.; Shaw, G.R.; Eaglesham, G.K. Human fatalities from cyanobacteria: Chemical and biological evidence for cyanotoxins. Environ. Health Perspect. 2001, 109, 663-668. [CrossRef]

6. Prieto, A.; Campos, A.; Camea, A. Effects on growth and oxidative stress status of rice plants (Oryza sativa) exposed to two extracts of toxin-producing cyanobacteria (Aphanizomenon ovalisporum and Microcystis aeruginosa). Ecotoxicol. Environ. Saf. 2011, 74, 1973-1980. [CrossRef]

7. Pantelić, D.; Svirčev, Z.; Simeunović, J.; Vidović, M.; Trajković, I. Cyanotoxins: Characteristics, production and degradation routes in drinking water treatment with reference to the situation in Serbia. Chemosphere 2013, 91, 421-441. [CrossRef]

8. Harada, K.-I.; Tsuji, K.; Watanabe, M.F.; Kondo, F. Stability of microcystins from cyanobacteria. III. Effect of $\mathrm{pH}$ and temperature. Phycologia 1996, 35, 83-88. [CrossRef]

9. Svirčev, Z.; Krstić, S.; Miladinov-Mikov, M.; Baltić, V.; Vidović, M. Freshwater cyanobacterial blooms and primary liver cancer epidemiological studies in Serbia. J. Environ. Sci. Health Part C 2009, 27, 36-55. [CrossRef]

10. Zhou, L.; Yu, H.; Chen, K. Relationship between microcystin in drinking water and colorectal cancer. Biomed. Environ. Sci. 2002, 15, 166-171.

11. Rastogi, R.P.; Sinha, R.P.; Incharoensakdi, A. The cyanotoxin-microcystins: Current overview. Rev. Environ. Sci. Biotechnol. 2014, 13, 215-249. [CrossRef]

12. Nawaz, M.; Moztahida, M.; Kim, J.; Shahzad, A.; Jang, J.; Miran, W.; Lee, D.S. Photodegradation of microcystin-LR using graphene- $\mathrm{TiO}_{2}$ /sodium alginate aerogels. Carbohydr. Polym. 2018, 199, 109-118. [CrossRef] [PubMed]

13. Zhang, X.; He, J.; Xiao, S.; Yang, X. Elimination kinetics and detoxification mechanisms of microcystin-LR during UV/Chlorine process. Chemosphere 2019, 214, 702-709. [CrossRef] [PubMed]

14. Wang, X.; Wang, X.; Zhao, J.; Song, J.; Zhou, L.; Wang, J.; Chen, Y. An alternative to in situ photocatalytic degradation of microcystin-LR by worm-like $\mathrm{N}, \mathrm{P}$ codoped $\mathrm{TiO}_{2}$ /expanded graphite by carbon layer (NPT-EGC) floating composites. Appl. Catal. B Environ. 2017, 206, 479-489. [CrossRef]

15. Lin, Y.-F.; Hsu, Y.-J. Interfacial charge carrier dynamics of type-II semiconductor nanoheterostructures. Appl. Catal. B Environ. 2013, 130, 93-98. [CrossRef]

16. Chen, M.-Y.; Hsu, Y.-J. Type-II nanorod heterostructure formation through one-step cation exchange. Nanoscale 2013, 5, 363-368. [CrossRef]

17. Nguyen, A.T.; Lin, W.-H.; Lu, Y.-H.; Chiou, Y.-D.; Hsu, Y.-J. First demonstration of rainbow photocatalysts using ternary $\mathrm{Cd}_{1-\mathrm{x}} \mathrm{Zn}_{\mathrm{x}}$ Se nanorods of varying compositions. Appl. Catal. A 2014, 476, 140-147. [CrossRef]

18. Pu, Y.-C.; Lin, W.-H.; Hsu, Y.-J. Modulation of charge carrier dynamics of $\mathrm{Na}_{\mathrm{x}} \mathrm{H}_{2-\mathrm{x}} \mathrm{Ti}_{3} \mathrm{O}_{7}-\mathrm{Au}^{-} \mathrm{Cu}_{2} \mathrm{O}$ Z-scheme nanoheterostructures through size effect. Appl. Catal. B Environ. 2015, 163, 343-351. [CrossRef]

19. Chen, Y.-C.; Katsumata, K.-i.; Chiu, Y.-H.; Okada, K.; Matsushita, N.; Hsu, Y.-J. ZnO-graphene composites as practical photocatalysts for gaseous acetaldehyde degradation and electrolytic water oxidation. Appl. Catal. A 2015, 490, 1-9. [CrossRef]

20. Chen, Y.-C.; Liu, T.-C.; Hsu, Y.-J. ZnSe· ${ }_{0.5} \mathrm{~N}_{2} \mathrm{H}_{4}$ Hybrid Nanostructures: A Promising Alternative Photocatalyst for Solar Conversion. ACS Appl. Mater. Interfaces 2015, 7, 1616-1623. [CrossRef] 
21. Lin, W.-H.; Chiu, Y.-H.; Shao, P.-W.; Hsu, Y.-J. Metal-Particle-Decorated ZnO Nanocrystals: Photocatalysis and Charge Dynamics. ACS Appl. Mater. Interfaces 2016, 8, 32754-32763. [CrossRef] [PubMed]

22. Pua, Y.-C.; Choub, H.-Y.; Kuoc, W.-S.; Wei, K.-H.; Hsu, Y.-J. Interfacial charge carrier dynamics of cuprous oxide-reduced graphene oxide $\left(\mathrm{Cu}_{2} \mathrm{O}-\mathrm{rGO}\right)$ nanoheterostructures and their related visible-light-driven photocatalysis. Appl. Catal. B Environ. 2017, 204, 21-32. [CrossRef]

23. Chiu, Y.-H.; Hsu, Y.-J. Au@Cuㄱ $\mathrm{S}_{4}$ yolk@shell nanocrystal-decorated $\mathrm{TiO}_{2}$ nanowires as an all-dayactive photocatalyst for environmental purification. Nano Energy 2017, 31, 286-295. [CrossRef]

24. Kuo, M.-Y.; Hsiao, C.-F.; Chiu, Y.-H.; Lai, T.-H.; Fang, M.-J.; Wu, J.-Y.; Chen, J.-W.; Wu, C.-L.; Wei, K.-H.; Lin, H.-C.; et al. Au@ $\mathrm{Cu}_{2} \mathrm{O}$ core@shell nanocrystals as dual-functional catalysts for sustainable environmental applications. Appl. Catal. B Environ. 2019, 242, 499-506. [CrossRef]

25. Chiu, Y.-H.; Chang, T.-F.M.; Chen, C.-Y.; Sone, M.; Hsu, Y.-J. Mechanistic Insights into Photodegradation of Organic Dyes Using Heterostructure Photocatalysts. Catalysts 2019, 9, 430. [CrossRef]

26. Robertson, P.K.J.; Lawton, L.A.; Munch, B.; Rouzade, J. Destruction of cyanobacterial toxins by semiconductor photocatalysis. Chem. Commun. 1997, 4, 393-394. [CrossRef]

27. Antoniou, M.G.; Nicolaou, P.A.; Shoemaker, J.A.; de la Cruz, A.A.; Dionysiou, D.D. Impact of the morphological properties of thin $\mathrm{TiO}_{2}$ photocatalytic films on the detoxification of water contaminated with the cyanotoxin, microcystin- LR. Appl. Catal. B Environ. 2009, 91, 165-173. [CrossRef]

28. Triantis, T.M.; Fotiou, T.; Kaloudis, T.; Kontos, A.G.; Falaras, P.; Dionysiou, D.D.; Pelaez, M.; Hiskia, A. Photocatalytic degradation and mineralization of microcystin-LR under UV-A, solar and visible light using nanostructured nitrogen doped $\mathrm{TiO}_{2}$. J. Hazard. Mater. 2012, 211, 196-202. [CrossRef]

29. Zhang, G.; Nadagouda, M.; O'Shea, K.; El-Sheikh, S.M.; Ismail, A.A.; Likodimos, V.; Falaras, P.; Dionysiou, D.D. Degradation of Cylindrospermopsin by Using Polymorphic Titanium Dioxide under UV-Vis Irradiation. Catal. Today 2014, 224, 49-55. [CrossRef]

30. Zhang, G.; He, X.; Nadagouda, M.; O'Shea, K.; El-Sheikh, S.M.; Ismail, A.A.; Dionysiou, D.D. Identification of photocatalytic destruction intermediates and reaction pathway of cylindrospermopsin by LC/Q-TOF-ESI-MS. Appl. Catal. B Environ. 2015, 163, 591-598. [CrossRef]

31. El-Sheikh, S.M.; Khedr, T.M.; Zhang, G.S.; Vogiazi, V.; Ismail, A.A.; O'Shea, K.; Dionysiou, D.D. Tailored synthesis of anatase-brookite heterojunction photocatalysts for degradation of cylindrospermopsin under UV-Vis light. Chem. Eng. J. 2017, 310, 428-436. [CrossRef]

32. Schneider, O.M.; Liang, R.; Bragg, L.; Jaciw-Zurakowsky, I.; Fattahi, A.; Rathod, S.; Peng, P.; Servos, M.R.; Zhou, Y.N. Photocatalytic Degradation of Microcystins by $\mathrm{TiO}_{2}$ Using UV-LED Controlled Periodic Illumination. Catalysts 2019, 9, 181. [CrossRef]

33. Chen, L.; Zhao, C.; Dionysiou, D.D.; O'Shea, K.E. $\mathrm{TiO}_{2}$ photocatalytic degradation and detoxification of cylindrospermopsin. J. Photochem. Photobiol. A Chem. 2015, 307, 115-122. [CrossRef]

34. Fotiou, T.; Triantis, T.; Kaloudis, T.; Hiskia, A. Photocatalytic degradation of cylindrospermopsin under UV-A, solar and visible light using $\mathrm{TiO}_{2}$. Mineralization and intermediate products. Chemosphere 2015, 119, S89-S94. [CrossRef]

35. Fotiou, T.; Triantis, T.M.; Kaloudis, T.; O'Shea, K.E.; Dionysiou, D.D.; Hiskia, A. Assessment of the roles of reactive oxygen species in the $\mathrm{UV}$ and visible light photocatalytic degradation of cyanotoxins and water taste and odor compounds using $\mathrm{C}-\mathrm{TiO}_{2}$. Water Res. 2016, 90, 52-61. [CrossRef]

36. Hu, X.; Hu, X.J.; Tang, C.F.; Wen, S.Z.; Wu, X.F.; Long, J.; Yang, X.; Wang, H.; Zhou, L. Mechanisms underlying degradation pathways of microcystin-LR with doped $\mathrm{TiO}_{2}$ photocatalysis. Chem. Eng. J. 2017, 330, 355-371. [CrossRef]

37. Kandiel, T.A.; Feldhoff, A.; Robben, L.; Dillert, R.; Bahnemann, D.W. Tailored titanium dioxide nanomaterials: Anatase nanoparticles and brookite nanorods as highly active photocatalysts. Chem. Mater. 2010, 22, 2050-2060. [CrossRef]

38. Shen, X.; Tian, B.; Zhang, J. Tailored preparation of titania with controllable phases of anatase and brookite by an alkalescent hydrothermal route. Catal. Today 2013, 201, 151-158. [CrossRef]

39. Khedr, T.M.; El-Sheikh, S.M.; Ismail, A.A.; Bahnemann, D.W. Highly Efficient Solar Light-Assisted $\mathrm{TiO}_{2}$ Nanocrystalline for Photodegradation of Ibuprofen Drug. Opt. Mater. 2019, 88, 117-127. [CrossRef]

40. Khedr, T.M.; El-Sheikh, S.M.; Ismail, A.A.; Bahnemann, D.W. Photodegradation of 4-aminoantipyrine over Nano-Titania Heterojunctions Using Solar and LED Irradiation Sources. J. Environ. Chem. Eng. 2019, 17, 102797. [CrossRef] 
41. Matsumoto, T.; Iyi, N.; Kaneko, Y.; Kitamura, K.; Ishihara, S.; Takasu, Y.; Murakami, Y. High visible-light photocatalytic activity of nitrogen-doped titania prepared from layered titania/isostearate nanocomposite. Catal. Today 2007, 120, 226-232. [CrossRef]

42. Dong, F.; Zhao, W.; Wu, Z. Characterization and photocatalytic activities of C, N and S co-doped $\mathrm{TiO}_{2}$ with 1D nanostructure prepared by the nano-confinement effect. Nanotechnology 2008, 19, 365-607. [CrossRef] [PubMed]

43. Liu, G.; Han, C.; Pelaez, M.; Zhu, D.; Liao, S.; Likodimos, V.; Kontos, A.G.; Falaras, P.; Dionysiou, D.D. Enhanced visible light photocatalytic activity of $\mathrm{CN}$-codoped $\mathrm{TiO}_{2}$ films for the degradation of microcystin-LR. J. Mol. Catal. A Chem. 2013, 372, 58-65. [CrossRef]

44. Andersen, J.; Han, C.; O'Shea, K.; Dionysiou, D.D. Revealing the degradation intermediates and pathways of visible light-induced $\mathrm{NF}^{-\mathrm{TiO}_{2}}$ photocatalysis of microcystin-LR. Appl. Catal. B Environ. 2014, 154, $259-266$. [CrossRef]

45. Zhang, G.; Zhang, Y.C.; Nadagouda, M.; Han, C.; O'Shea, K.; El-Sheikh, S.M.; Ismail, A.A.; Dionysiou, D.D. Visible light-sensitized $\mathrm{S}, \mathrm{N}$ and $\mathrm{C}$ co-doped polymorphic $\mathrm{TiO}_{2}$ for photocatalytic destruction of microcystin-LR. Appl. Catal. B Environ. 2014, 144, 614-621. [CrossRef]

46. Ma, D.; Xin, Y.; Gao, M.; Wu, J. Fabrication and photocatalytic properties of cationic and anionic S-doped $\mathrm{TiO}_{2}$ nanofibers by electrospinning. Appl. Catal. B Environ. 2014, 147, 49-57. [CrossRef]

47. El-Sheikh, S.M.; Khedr, T.M.; Hakki, A.; Ismail, A.A.; Badawy, W.A.; Bahnemann, D.W. Visible Light Activated Carbon and Nitrogen Co-doped Mesoporous $\mathrm{TiO}_{2}$ as Efficient Photocatalyst for Degradation of Ibuprofen. Sep. Purif. Technol. 2017, 173, 258-268. [CrossRef]

48. Khedr, T.M.; El-Sheikh, S.M.; Hakki, A.; Ismail, A.A.; Badawy, W.A.; Bahnemann, D.W. Highly active non-metals doped mixed-phase $\mathrm{TiO}_{2}$ for photocatalytic oxidation of ibuprofen under visible light. J. Photochem. Photobiol. A Chem. 2017, 346, 530-540. [CrossRef]

49. Fiorenza, R.; Bellardita, M.; Scirè, S.; Palmisano, L. Effect of the addition of different doping agents on visible light activity of porous $\mathrm{TiO}_{2}$ photocatalysts. Mol. Catal. 2018, 455, 108-120. [CrossRef]

50. Abdelraheem, W.H.M.; Patil, M.K.; Nadagouda, M.N.; Dionysiou, D.D. Hydrothermal synthesis of photoactive nitrogen- and boron- codoped $\mathrm{TiO}_{2}$ nanoparticles for the treatment of bisphenol A in wastewater: Synthesis, photocatalytic activity, degradation byproducts and reaction pathways. Appl. Catal. B 2019, 241, 598-611. [CrossRef]

51. Ma, Y.F.; Zhang, J.L.; Tian, B.Z.; Chen, F.; Wang, L.Z. Synthesis and characterization of thermally stable Sm, $\mathrm{N}$ co-doped $\mathrm{TiO}_{2}$ with highly visible light activity. J. Hazard. Mater. 2010, 182, 386-393. [CrossRef] [PubMed]

52. Nguyen, T.-B.; Hwang, M.-J.; Ryu, K.-S. High adsorption capacity of V-doped $\mathrm{TiO}_{2}$ for decolorization of methylene blue. Appl. Surf. Sci. 2012, 258, 7299-7305. [CrossRef]

53. Marschall, R.; Wang, L. Non-metal doping of transition metal oxides for visible-light photocatalysis. Catal. Today 2014, 225, 111-135. [CrossRef]

54. Liu, S.X.; Liu, J.L.; Li, X.S.; Zhu, X.; Zhu, A.M. Gliding arc plasma synthesis of visible light active C-doped titania photocatalysts. Plasma Process. Polym. 2015, 12, 422-430. [CrossRef]

55. Li, M.; Zhang, S.; Peng, Y.; Lv, L.; Pan, B. Enhanced visible light responsive photocatalytic activity of $\mathrm{TiO}_{2}$-based nanocrystallites: Impact of doping sequence. RSC Adv. 2015, 5, 7363-7369. [CrossRef]

56. Pinho, L.X.; Azevedo, J.; Brito, A.; Santos, A.; Tamagnini, P.; Vilar, V.J.P.; Vasconcelos, V.M.; Boaventura, R.A.R. Effect of $\mathrm{TiO}_{2}$ photocatalysis on the destruction of Microcystis aeruginosa cells and degradation of cyanotoxins microcystin-LR and cylindrospermopsin. Chem. Eng. J. 2015, 268, 144-152. [CrossRef]

57. Tsuji, K.; Watanuki, T.; Kondo, F.; Watanabe, M.F.; Suzuki, S.; Nakazawa, H.; Suzuki, M.; Uchida, H.; Harada, K.-I. Stability of microcystins from cyanobacteria-II. Effect of UV light on decomposition and isomerization. Toxicon 1995, 33, 1619-1631. [CrossRef]

58. Welker, M.; Steinberg, C. Indirect photolysis of cyanotoxins: One possible mechanism for their low persistence. Water Res. 1999, 33, 1159-1164. [CrossRef]

59. Lawton, L.; Robertson, P.; Cornish, B.; Jaspars, M. Detoxification of microcystins (cyanobacterial hepatotoxins) using $\mathrm{TiO}_{2}$ photocatalytic oxidation. Environ. Sci. Technol. 1999, 33, 771-775. [CrossRef]

60. Lawton, L.; Robertson, P.; Cornish, B.; Marr, I.; Jaspars, M. Processes influencing surface interaction and photocatalytic destruction of microcystins on titanium dioxide photocatalysts. J. Catal. 2003, 213, 109-113. [CrossRef] 
61. Van Apeldoorn, M.E.; Van Egmond, H.P.; Speijers, G.J.A.; Bakker, G.J.I. Toxins of cyanobacteria. Mol. Nutr. Food Res. 2007, 51, 7-60. [CrossRef] [PubMed]

62. Pinho, L.X.; Azevedo, J.; Vasconcelos, V.M.; Vilar, V.J.P.; Boaventura, R.A.R. Decomposition of Microcystis aeruginosa and microcystin-LR by $\mathrm{TiO}_{2}$ oxidation using artificial UV light or natural sunlight. J. Adv. Oxid. Technol. 2012, 15, 98-106. [CrossRef]

63. Vilela, W.F.D.; Minillo, A.; Rocha, O.; Vieira, E.M.; Azevedo, E.B. Degradation of [D-Leu]-icrocystin-LR by solar heterogeneous photocatalysis $\left(\mathrm{TiO}_{2}\right)$. Sol. Energy 2012, 86, 2746-2752. [CrossRef]

64. Liao, W.; Zhang, Y.; Zhang, M.; Murugananthan, M.; Yoshihara, S. Photoelectrocatalytic degradation of microcystin-LR using $\mathrm{Ag} / \mathrm{AgCl} / \mathrm{TiO}_{2}$ nanotube arrays electrode under visible light irradiation. Chem. Eng. J. 2013, 231, 455-463. [CrossRef]

65. Ismail, A.A.; Bahnemann, D.W. Mesoporous titania photocatalysts: Preparation, characterization and reaction mechanisms. J. Mater. Chem. 2011, 21, 11686-11707. [CrossRef]

66. Atitar, M.F.; Ismail, A.A.; Al-Sayari, S.A.; Bahnemann, D.; Afanasev, D.; Emeline, A.V. Mesoporous $\mathrm{TiO}_{2}$ nanocrystals as efficient photocatalysts: Impact of calcination temperature and phase transformation on photocatalytic Performance. Chem. Eng. J. 2015, 264, 417-424. [CrossRef]

67. Jallouli, N.; Elghniji, K.; Trabelsi, H.; Ksibi, M. Photocatalytic degradation of paracetamol on $\mathrm{TiO}_{2}$ nanoparticles and $\mathrm{TiO}_{2}$ /cellulosic fiber under UV and sunlight irradiation. Arabian J. Chem. 2017, 10, S3640-S3645. [CrossRef]

68. Lü, X.; Mao, D.; Wei, X.; Zhang, H.; Xie, J.; Wei, W. Tunable synthesis of enhanced photodegradation activity of brookite/anatase mixed-phase titanium dioxide. J. Mater. Res. 2013, 28, 400-404. [CrossRef]

69. Azeez, F.; Al-Hetlani, E.; Arafa, M.; Abdelmonem, Y.; Abdel Nazeer, A.; Amin, M.O.; Madkour, M. The effect of surface charge on photocatalytic degradation of methylene blue dye using chargeable titania nanoparticles. Sci. Rep. 2018, 8, 7104. [CrossRef]

70. Chen, D.; Jiang, Z.; Geng, J.; Wang, Q.; Yang, D. Carbon and nitrogen co-doped $\mathrm{TiO}_{2}$ with enhanced visible-light photocatalytic activity. Ind. Eng. Chem. Res. 2007, 46, 2741-2746. [CrossRef]

71. Wang, D.-H.; Jia, L.; Wu, X.-L.; Lu, L.Q.; Xu, A.-W. One-step hydrothermal synthesis of N-doped $\mathrm{TiO}_{2} / \mathrm{C}$ nanocomposites with high visible light photocatalytic activity. Nanoscale 2012, 4, 576-584. [CrossRef] [PubMed]

72. He, X.; Pelaez, M.; Westrick, J.A.; O'Shea, K.E.; Hiskia, A.; Triantis, T.; Kaloudis, T.; Stefan, M.I.; de la Cruz, A.A.; Dionysiou, D.D. Efficient removal of microcystin-LR by UV-C/ $\mathrm{H}_{2} \mathrm{O}_{2}$ in synthetic and natural water samples. Water Res. 2012, 46, 1501-1510. [CrossRef] [PubMed] 